\title{
Adhesion of Staphylococcus epidermidis and Staphylococcus saprophyticus to a Hydrophobic Biomaterial
}

\author{
By ANDRE H. HOGT, ${ }^{1}$ JACOB DANKERT ${ }^{2 *}$ AND JAN FEIJEN ${ }^{1}$ \\ ${ }^{1}$ Department of Chemical Technology, Section of Biomaterials, Twente University of Technology, \\ PO Box 217, 7500 AE Enschede, The Netherlands \\ ${ }^{2}$ Laboratory for Medical Microbiology and Department of Hospital Epidemiology, University \\ Hospital, Oostersingel 59, 9700 RB Groningen, The Netherlands
}

(Received 1 October 1984; revised 20 March 1985)

The relative surface charge and hydrophobicity of 16 strains of Staphylococcus epidermidis showed large variations. For this species no relationship between the two surface parameters was found. A highly negative surface charge was observed in all seven encapsulated strains (one $S$. epidermidis and six Staphylococcus saprophyticus strains). The adhesion of the staphylococci to fluorinated polyethylene-propylene films was not related to the relative surface charge and the hydrophobicity of the bacteria. On films pre-exposed to human plasma, the bacterial adhesion was substantially reduced. Mechanisms involved in the adhesion of coagulase-negative staphylococci to this biomaterial are discussed.

\section{INTRODUCTION}

Infections associated with prosthetic implants and medical devices are mostly caused by coagulase-negative staphylococci (CNS) (Garvey, 1980). Adhesion of bacteria to tissue surfaces of the host and to implanted artificial surfaces is considered to be an important step in the pathogenesis of infections (Ofek \& Beachey, 1980). The mechanism of the adhesion of CNS to artificial surfaces has been studied (Locci et al., 1981; Christensen et al., 1983) but remains unclear. In many adhesion studies bacteria were applied to various surfaces in (physiological) salt solutions. However, artificial surfaces in contact with body fluids are usually rapidly coated with proteins (Feijen et al., 1979), which means that the adhesion also has to be studied using protein-coated surfaces. Electrostatic and hydrophobic interactions between bacteria and protein-coated surfaces may be involved in bacterial adhesion (Rutter \& Vincent, 1980; Doyle $e t$ $a l ., 1982)$. The adhesion of various oral bacteria to hydroxyapatite coated with salivary protein is related to the hydrophobic character of the bacteria (Gibbons \& Etherden, 1983). The adhesion of Streptococcus mutans to such a surface appeared to be mediated by short range hydrophobic and ionic interactions (Reynolds \& Wong, 1983). These findings indicate that the surface charge and hydrophobicity of bacteria used in adhesion studies might be important.

This paper describes the relative surface charge and hydrophobicity of various encapsulated and non-encapsulated strains of Staphylococcus epidermidis and Staphylococcus saprophyticus. The adhesion of these strains to fluorinated polyethylene-propylene (FEP) films and to FEP films pre-exposed to citrated human plasma was investigated.

\section{METHODS}

Coagulase-negative staphylococci. A total of 23 CNS strains were used. Six Staphylococcus epidermidis strains (NCTC) were a gift of Dr R. R. Marples, Central Public Health Laboratory, Colindale Avenue, London, UK. These strains were derived from patients with prosthetic endocarditis. The remaining 17 strains were isolated from the skin of open-heart surgery patients and laboratory staff members. CNS were identified according to the scheme of Kloos \& Schleifer (1975) using the API Staph gallery.

Abbreviations: CNS, coagulase-negative staphylococci; FEP, fluorinated polyethylene-propylene; TSB, trypticase soy broth. 
Bacteria were cultured for $4.5 \mathrm{~h}$ in Trypticase Soy Broth (TSB; BBL) as previously described (Hogt et al., 1983a). Bacteria grown on sheep blood agar plates (Oxoid) and in TSB were stained using the India ink wet-film method to demonstrate the presence of capsules (Duguid, 1951). In all experiments late exponential phase cells were used. Bacteria were washed three times with $0.14 \mathrm{M}-\mathrm{NaCl} / \mathrm{phosphate}$ buffer $(0.14 \mathrm{M}-\mathrm{NaCl}, 3 \mathrm{mM}-\mathrm{KCl}$, $8.4 \mathrm{mM}-\mathrm{Na}_{2} \mathrm{HPO}_{4}, 1.6 \mathrm{mM}-\mathrm{KH}_{2} \mathrm{PO}_{4} ; \mathrm{pH} \mathrm{7.2)}$.

Relative bacterial surface charge. The relative surface charge of bacteria was tested by their adhesion to an anionexchange resin according to a modified procedure of Pedersen (1981). The bacteria were not labelled and a $0 \cdot 33 \mathrm{M}-$ $\mathrm{NaCl} /$ phosphate buffer $\left(0.33 \mathrm{M}-\mathrm{NaCl}, 3 \mathrm{mM}-\mathrm{KCl}, 8.4 \mathrm{mM}-\mathrm{Na}_{2} \mathrm{HPO}_{4}, 1.6 \mathrm{mM}-\mathrm{KH}_{2} \mathrm{PO}_{4} ; \mathrm{pH} 7.2\right)$ was used for suspension and elution of the bacteria. The bacterial cell concentration in suspension was determined by measuring the optical density at $540 \mathrm{~nm}$ (Beckman model 24 spectrophotometer). Suspensions with an OD ${ }_{540}$ of 1.0 containing approximately $10^{9}$ c.f.u. $\mathrm{ml}^{-1}$, as determined by colony count, were used in all experiments. Pasteur pipettes (inner diameter $5 \mathrm{~mm}$ ) containing $0.5 \mathrm{~g}$ anion-exchange resin (Dowex $1 \times 8$ mesh size 100/200, 80$150 \mu \mathrm{m}$; Serva, Heidelberg, FRG) were first rinsed with $0.33 \mathrm{M}-\mathrm{NaCl} / \mathrm{phosphate}$ buffer and then $1 \mathrm{ml}$ of the bacterial suspension in $0.33 \mathrm{M}-\mathrm{NaCl} /$ phosphate buffer was applied to the columns. The columns were eluted with $8 \mathrm{ml} 0.33 \mathrm{M}-\mathrm{NaCl} / \mathrm{phosphate}$ buffer and the OD of the eluate was measured. The relative surface charge of the bacteria was expressed as the percentage of the bacteria bound to the anion-exchange resin.

In order to study the effect of ionic strength of the buffer on binding of bacteria to the resin, bacteria were eluted with $\mathrm{NaCl}$ /phosphate buffers containing $0.03 \mathrm{M}-\mathrm{KCl}$ and $\mathrm{NaCl}$ concentrations ranging from 0.14 to $0.66 \mathrm{M}$ or with phosphate buffer without $\mathrm{NaCl}$ and $\mathrm{KCl}$. The effect of ionic strength of the buffer on the recovery of bacteria from the resin was studied as follows. Bacteria, suspended in $0.14 \mathrm{M}-\mathrm{NaCl} /$ phosphate buffer, were applied to the resin and eluted with the same buffer. The resin was then collected and resuspended in $3 \mathrm{ml} \mathrm{NaCl} / \mathrm{phosphate}$ buffer with $\mathrm{NaCl}$ concentrations ranging from 0.14 to $1.20 \mathrm{M}$ in round-bottomed test tubes which were gently shaken four times with intervals of $3 \mathrm{~min}$. After an additional $10 \mathrm{~min}$ in which the resin settled, the $O D$ of the supernate was measured and the number of c.f.u. was determined using the pour plate method.

Bacterial surface hydrophobicity. Bacterial cell-surface hydrophobicity was determined by measuring the bacterial adhesion to xylene in a xylene-water system according to Rosenberg et al. (1980). Washed bacteria were suspended in $3 \mathrm{ml} \mathrm{0.14} \mathrm{M}-\mathrm{NaCl} /$ phosphate buffer to an $\mathrm{OD}_{540}$ of $1 \cdot 0$. A volume of $0.25 \mathrm{ml}$-xylene (Merck) was added to disposable glass test tubes $(10 \mathrm{~mm}$ inner diameter) containing the bacterial suspensions. The tube contents were mixed on a vortex mixer for $60 \mathrm{~s}$ and after phase separation occurred, the OD of the aqueous phase was measured. The hydrophobicity of the bacteria was expressed as the percentage of bacteria that adhered to xylene.

Polymer films and pre-exposure to plasma. The polymer films used for the bacterial adhesion experiments were fluorinated polyethylene-propylene (FEP) films (type ' $500 \mathrm{~A}$ '; DuPont). FEP is a hydrophobic biomaterial used in various biomedical devices. The preparation of the polymer film test specimens was described previously in detail (Hogt et al., 1983a).

In order to investigate bacterial adhesion to protein-coated films, polymer films were pre-exposed to citrated human plasma. Citrated fresh plasma (CPDA-1; Bloedbank, Groningen, The Netherlands) was stored at $-20^{\circ} \mathrm{C}$. FEP films were rinsed with $0 \cdot 14 \mathrm{M}-\mathrm{NaCl} /$ phosphate buffer and exposed to $3 \mathrm{ml}$ plasma for $1 \mathrm{~h}$ at $37^{\circ} \mathrm{C}$. The films were then rinsed eight times with $3 \mathrm{ml}$ amounts of $\mathrm{NaCl} /$ phosphate buffer. Control films were exposed only to $\mathrm{NaCl} /$ phosphate buffer.

Contact angle measurements. Water contact angles of FEP films and FEP films pre-exposed to plasma were measured by the captive bubble method (Adamson, 1967). Polymer films were attached to a panel which was submerged in hyperfiltrated water at $21^{\circ} \mathrm{C}$ in a Perspex chamber. Hyperfiltrated water was prepared by ultrafiltration of demineralized water through polysulfon membranes (Wavilin, Hardenberg, The Netherlands) and then hyperfiltration using a hollow fibre configuration RO module (Hollosep, type HR 8650; Toyobo, Japan). An air bubble was released from a microlitre syringe tip beneath the polymer films and allowed to rise to a film surface. The air bubble was then photographed within $30 \mathrm{~s}$ after contact with the film. The height $(h)$ of the bubble and the width $(b)$ of the bubble interface with the film were measured. The contact angle $\theta=180^{\circ}-2 \operatorname{arctg}(2 h / b)$. Measurements were made in triplicate.

Bacterial adhesion to polymer films. Bacterial suspensions in $0.14 \mathrm{M}-\mathrm{NaCl} / \mathrm{phosphate} \mathrm{buffer} \mathrm{were} \mathrm{filtered} \mathrm{through}$ membrane filters ('Uni-pore', pore size $3 \mu \mathrm{m}$; Bio-Rad) to remove clusters. Details of the procedure for bacterial adhesion experiments were previously described (Hogt et al., 1983a). The polymer films were exposed to bacterial suspensions with an $\mathrm{OD}_{540}$ of 0.5 containing $5 \times 10^{8} \mathrm{cells} \mathrm{ml}^{-1}$ for $2.5 \mathrm{~h}$ at $37^{\circ} \mathrm{C}$ in a rotary shaker/incubator (New Brunswick Scientific; 90 r.p.m.). Films were then rinsed eight times with $3 \mathrm{ml}$ amounts of $\mathrm{NaCl} / \mathrm{phosphate}$ buffer and treated with $2 \%(\mathrm{w} / \mathrm{v})$ glutaraldehyde in $\mathrm{NaCl} / \mathrm{phosphate}$ buffer for $5 \mathrm{~min}$. Subsequently, the films were rinsed with distilled water and dried at room temperature. All adhesion experiments were done at least twice. The number of adhering cells per $\mathrm{mm}^{2}$ of film was determined using a light microscope by examining six $0.05 \mathrm{~mm}^{2}$ areas on each film. 


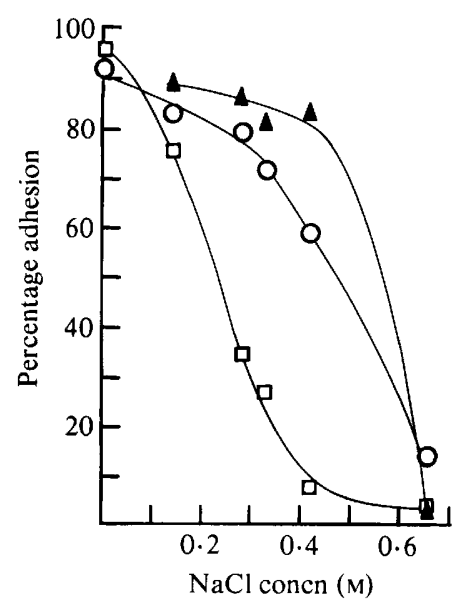

Fig. 1

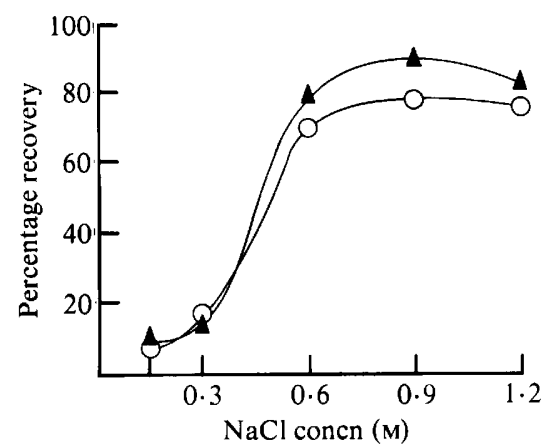

Fig. 2

Fig. 1. Percentage of bacteria adhering to an anion-exchange column as a function of the $\mathrm{NaCl}$ concentration in the elution buffer. Washed bacteria $\left(1 \times 10^{9}\right)$ of two non-encapsulated $S$. epidermidis strains (SEP 2, O; SL 58, $\square$ ) and one encapsulated $S$. saprophyticus strain (SAP 1, $\mathbf{A}$ ) were suspended in $1.0 \mathrm{ml} \mathrm{NaCl} / \mathrm{phosphate}$ buffer $(\mathrm{pH} \mathrm{7.2)}$ with different $\mathrm{NaCl}$ concentrations and then applied to the column.

Fig. 2. Recovery of bacteria from anion-exchange resin in $\mathrm{NaCl} /$ phosphate buffer with different $\mathrm{NaCl}$ concentrations. Washed bacteria $\left(1 \times 10^{9}\right)$ of a non-encapsulated $S$. epidermidis strain $(\mathrm{SEP} 2, \mathrm{O})$ and an encapsulated $S$. saprophyticus strain (SAP 1, $\boldsymbol{\Delta}$ ) both suspended in $1.0 \mathrm{ml} 0.14 \mathrm{M}-\mathrm{NaCl} / \mathrm{phosphate}$ buffer were applied to the resin and eluted with the same buffer. Resins with adsorbed bacteria were then suspended in $\mathrm{NaCl}$ /phosphate buffer with different $\mathrm{NaCl}$ concentrations.

\section{RESULTS}

Surface character of S. epidermidis and S. saprophyticus

Sixteen $S$. epidermidis strains and seven $S$. saprophyticus strains were studied. Capsules were demonstrated in only one $S$. epidermidis strain and in six $S$. saprophyticus strains. Capsules were present both around late exponential phase and stationary phase cells grown on blood agar or TSB.

The relative bacterial surface charge, as measured by bacterial adhesion to anion-exchange resin, was dependent on the salt concentration of the buffer used. The retention of bacteria in the anion-exchange column decreased with increasing salt concentration of the buffer solution (Fig. 1). At salt concentrations between $0 \cdot 14$ and $0.42 \mathrm{M}-\mathrm{NaCl}$ there was a significant difference between the adhesion of two non-encapsulated $S$. epidermidis strains and one encapsulated $S$. saprophyticus strain. Bacteria suspended in the phosphate buffer containing $0.66 \mathrm{M}-\mathrm{NaCl}$ showed a very low adhesion to the resin.

Recovery of bacteria from the anion-exchange resin was tested for an encapsulated $S$. saprophyticus strain and one non-encapsulated $S$. epidermidis strain (Fig. 2). The recovery of bacteria of both strains increased when phosphate buffers with increasing salt concentrations were used. A plateau value was reached using buffer containing $0.60 \mathrm{M}-\mathrm{NaCl}$.

In order to determine the relative bacterial surface charge of CNS, anion-exchange resin columns were eluted with $0.33 \mathrm{M}-\mathrm{NaCl} /$ phosphate buffer. Bacteria of the different strains of $S$. epidermidis and $S$. saprophyticus showed a wide range in adhesion to the resin varying from 17 to $100 \%$ (Table 1 ).

The relative surface hydrophobicity of different strains was determined by bacterial adhesion to xylene. The adhesion of encapsulated as well as non-encapsulated strains to xylene showed a wide range (3-89\%), indicating that different strains varied from hydrophilic to hydrophobic (Table 1). The hydrophobicity of stationary phase cells was similar to that of late exponential phase cells (results not shown). 
Table 1. Relative surface charge and hydrophobicity of strains of S. epidermidis and $S$. saprophyticus

The relative surface charge was determined by bacterial adhesion to anion-exchange resin. Bacterial suspensions in $0.33 \mathrm{M}-\mathrm{NaCl} /$ phosphate buffer $(1 \mathrm{ml})$ containing $10^{9}$ cells were applied to columns containing $0.5 \mathrm{~g}$ Dowex $1 \times 8$ resin and eluted with $0.33 \mathrm{M}-\mathrm{NaCl} /$ phosphate buffer. The bacterial hydrophobicity was measured by the adhesion to xylene. Bacterial suspensions in $0 \cdot 14 \mathrm{M}$ $\mathrm{NaCl} /$ phosphate buffer $(3 \mathrm{ml})$ containing $10^{9}$ cells $\mathrm{ml}^{-1}$ were vortexed for $60 \mathrm{~s}$ with $0.25 \mathrm{ml}$ xylene. Further details are given in Methods. The results shown are mean values of duplicate measurements.

\begin{tabular}{|c|c|c|c|}
\hline & & \multicolumn{2}{|c|}{ Percentage bacterial adhesion to } \\
\hline $\begin{array}{l}\text { Species and } \\
\text { strain no. }\end{array}$ & Capsule & $\begin{array}{l}\text { Anion-exchange } \\
\text { resin }\end{array}$ & Xylene \\
\hline \multicolumn{4}{|l|}{ S. epidermidis } \\
\hline NCTC 100893 & - & 22 & 49 \\
\hline SEP 1 & - & 23 & 77 \\
\hline GB 350 & - & 24 & 77 \\
\hline SL 58 & - & 27 & 75 \\
\hline H 1 & - & 43 & 71 \\
\hline NCTC 100600 & - & 45 & 50 \\
\hline NCTC 100894 & - & 47 & 74 \\
\hline K 2 & - & 55 & 16 \\
\hline PRE 69 & - & 58 & 82 \\
\hline I 41 & - & 61 & 71 \\
\hline SL 76 & - & 63 & 42 \\
\hline G 1 & - & 64 & 44 \\
\hline NCTC 100623 & - & 68 & 4 \\
\hline NCTC 100835 & - & 70 & 3 \\
\hline SEP 2 & - & 72 & 86 \\
\hline NCTC 100892 & + & 99 & 72 \\
\hline \multicolumn{4}{|l|}{ S. saprophyticus } \\
\hline PRE 40 & - & 17 & 52 \\
\hline SAP 1 & + & 79 & 6 \\
\hline GB 103 & + & 90 & 86 \\
\hline GB 51 & + & 94 & 75 \\
\hline GB 171 & + & 96 & 89 \\
\hline GB 149 & + & 99 & 87 \\
\hline A 1 & + & 100 & 89 \\
\hline
\end{tabular}

Bacterial adhesion to polymer films

The number of bacteria of the 15 non-encapsulated strains of $S$. epidermidis and the nonencapsulated $S$. saprophyticus strain that adhered to the FEP films ranged from 64 to $99 \times$ $10^{3}$ cells $\mathrm{mm}^{-2}$, while that of the five encapsulated strains of $S$. saprophyticus and the encapsulated $S$. epidermidis strain ranged widely (Fig. $3 a, b$ ). The difference between the adhesion values of the encapsulated and those of the non-encapsulated strains was significant $(P<0.001$ in Student's $t$-test; Fisher \& Yates, 1957). The encapsulated cells, in contrast to the non-encapsulated cells, always adhered in clusters. The adhesion did not correlate with either the bacterial relative surface charge (Fig. $3 a$ ), or with the bacterial hydrophobicity (Fig. $3 b$ ).

FEP films pre-exposed to plasma showed a strongly reduced water contact angle $\left(20^{\circ}\right)$ with respect to that of untreated FEP films $\left(103^{\circ}\right)$. Adhesion of all strains to FEP films pre-exposed to plasma was substantially reduced except for the encapsulated $S$. epidermidis (NCTC 100892) (Fig. $3 a, b)$. The mean adhesion values of hydrophilic ( $\leqslant 50 \%$ adhesion to xylene) and hydrophobic ( $>50 \%$ adhesion to xylene) non-encapsulated strains to plasma-treated FEP were not significantly different $(P>0.05)$. 

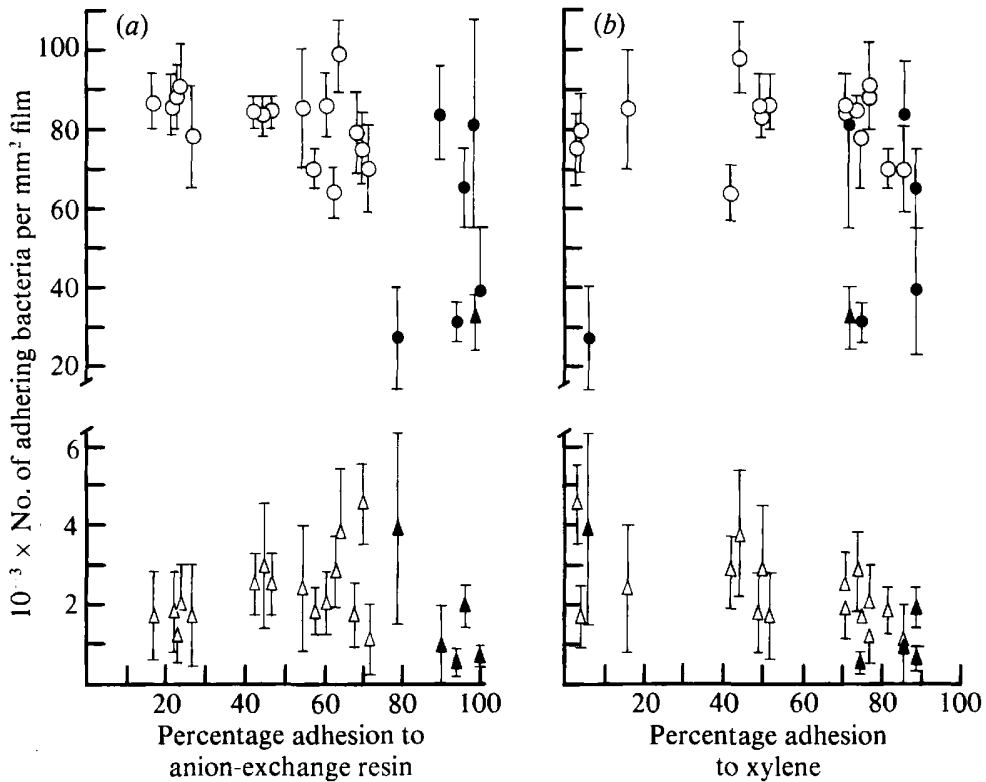

Fig. 3. Number of $S$. epidermidis and $S$. saprophyticus adhering to fluorinated polyethylene-propylene (FEP) films $(\boldsymbol{O}, O)$ and FEP films pre-exposed to citrated human plasma $(\triangle, \boldsymbol{\Delta})$ in relation to the percentage bacterial adhesion to anion-exchange resin $(a)$ and to xylene $(b)$. Adhesion experiments were done with bacteria $\left(5 \times 10^{8}\right.$ c.f.u. $\left.\mathrm{ml}^{-1}\right)$ of 16 strains of $S$. epidermidis and 6 strains of $S$. saprophyticus for $2.5 \mathrm{~h}$ at $37^{\circ} \mathrm{C}$ in $0.14 \mathrm{M}-\mathrm{NaCl} /$ phosphate buffer. Open symbols represent adhesion numbers of nonencapsulated bacteria; filled symbols represent those of encapsulated bacteria; bars denote SD.

\section{DISCUSSION}

The relative surface charge of various strains of Staphylococcus epidermidis and Staphylococcus saprophyticus showed a wide range, as indicated by adhesion to anion-exchange resin. The electrostatic bonding of CNS to the resin was reversible. Wood (1980) studied the desorption of Staphylococcus aureus from an anion-exchange resin in buffers containing different salt concentrations, and found that at concentrations higher than $0.6 \mathrm{M}-\mathrm{NaCl}$ the desorption was minimal due to a salting out effect. CNS were recovered from the resin in buffers with salt concentrations higher than $0.6 \mathrm{M}$ without a salting out effect. This indicates differences between the cell surface constituents of $S$. aureus and CNS.

The relative negative surface charge of encapsulated CNS was high, probably due to the presence of many negatively charged groups within the capsular polysaccharide material (Ichiman \& Yoshida, 1981). The relative negative surface charge of non-encapsulated CNS strains ranged widely as was demonstrated also by Pedersen (1981) for various marine bacteria.

CNS showed either a hydrophilic or a hydrophobic cell surface, as tested by their adhesion to xylene. No direct correlation was found between the relative surface charge and the hydrophobicity of the cells. Encapsulated CNS, except for one S. saprophyticus strain, were hydrophobic. Generally, encapsulated bacteria are more hydrophilic than non-encapsulated bacteria (van Oss \& Gillman, 1972). Hyaluronic acid-containing capsules of exponential phase cells of Streptococcus pyogenes (Ofek et al., 1983) and polysaccharide capsules of Acinetobacter calcoaceticus (Rosenberg et al., 1983) prevented the adhesion to hexadecane, indicating that such encapsulated bacteria are hydrophilic. Stationary phase cells of both species lost their capsules and showed a high affinity to hexadecane (Ofek et al., 1983; Rosenberg et al., 1983). Cells of encapsulated CNS had capsules in both their exponential and stationary growth phase. The hydrophobicity of the cells did not change significantly with the growth phase.

Usually bacterial hydrophobicity as determined by the adhesion to hydrocarbons correlates well with that obtained using octyl sepharose chromatography (Olsson \& Westergren, 1982; 
Rosenberg, 1984). In general, a high bacterial surface charge is accompanied by a more hydrophilic character of the cells. However, some strains of marine bacteria with a high relative surface charge possess exposed hydrophobic sites, as determined with octyl sepharose chromatography (Pedersen, 1981). Some CNS strains also showed a high relative surface charge combined with a high hydrophobicity. Little is known about the localization and distribution of surface components which mediate bacterial adhesion to hydrocarbons (Rosenberg, 1984). Yoshida \& Minegishi (1979) reported that an encapsulated S. epidermidis strain had proteincontaining spike-like structures protruding from the cell wall. Such protein structures might contribute to the expression of hydrophobic sites at the capsular surface. The differences in hydrophobicity between CNS strains, encapsulated or non-encapsulated, must be ascribed to differences in the exposure of hydrophobic residues at the surface. These may be proteins or glycolipids complexed to proteins because treatment of the bacteria with pepsin decreases their hydrophobicity (Hogt et al., 1983b).

The number of encapsulated and non-encapsulated $S$. epidermidis and $S$. saprophyticus that adhered to FEP and FEP pre-exposed to plasma appeared to be unrelated to the relative bacterial surface charge or to the bacterial hydrophobicity. These findings are in contrast to those reported by Gibbons \& Etherden (1983). They showed that the adhesion of various oral bacterial species to saliva-coated hydroxyapatite was related to the hydrophobicity of the bacterial strains.

The number of encapsulated CNS adhering in clusters to FEP films was significantly less than that of non-encapsulated CNS. This decreased adhesion may be due to bacterial aggregation of these strains in suspension. However, bacterial aggregation of encapsulated strains was similar to or less than that of non-encapsulated strains (Hogt et al., 1983a).

The adhesion of CNS to FEP may be mediated by protein-containing residues at the cell wall probably by hydrophobic bonding, since proteolytic enzyme pretreatment decreased the bacterial hydrophobicity and the adhesion to FEP (Hogt et al., 1983a). The reduced adhesion of CNS to FEP pre-exposed to plasma may be due to the decreased hydrophobicity of the FEP films by the adsorbed protein layer, as measured by determining contact angles. Fletcher \& Marshall (1982) studying the adhesion of Pseudomonas species to polystyrene surfaces also reported that adsorbed proteins lowered the hydrophobicity of polymer surfaces and decreased bacterial adhesion. In addition, electrostatic repulsion between bacteria and the FEP surface caused by the adsorbed protein may reduce bacterial adhesion (Reynolds \& Wong, 1983).

This work was supported by a grant from the Netherlands Organization for the Advancement of Pure Research (Z.W.O.).

\section{REFERENCES}

Adamson, A. W. (1967). Physical Chemistry of Surfaces, 2nd edn, pp. 352-369. New York: Interscience Publishers.

Christensen, G. D., Simpson, W. A., Bisno, A. L. \& BEACHEY, E. H. (1983). Experimental foreign body infections in mice challenged with slime-producing Staphylococcus epidermidis. Infection and Immunity 40, 407-410.

Doyle, R. J., Nesbitt, W. E. \& Taylor, K. G. (1982). On the mechanism of adherence of Streptococcus sanguis to hydroxylapatite. FEMS Microbiology Letters 15, 1-5.

Duguid, J. P. (1951). The demonstration of bacterial capsules and slime. Journal of Pathology and Bacteri$\operatorname{ology} 63,673-685$.

Feijen, J., Beugeling, T., Bantjes, A. \& Smit SiBingA, C. TH. (1979). Biomaterials and interfacial phenomena. In Advances in Cardiovascular Physics, vol. 3, pp. 100-134. Edited by D. N. Ghista. Basel: S. Karger.
FISHER, R. A. \& YATES, F. (1957). Statistical Methods for Biological, Agricultural and Medical Research. Edinburgh: Oliver \& Boyd.

Fletcher, M. \& Marshall, K. C. (1982). Bubble contact angle method for evaluating substratum interfacial characteristics and its relevance to bacterial attachment. Applied and Environmental Microbiology 44, 184-192.

GaRveY, G. (1980). Endovascular and prosthetic implant infections. In Infections in the Abnormal Host, pp. 693-745. Edited by M. H. Grieco. New York: Yorke Medical Books.

Gibbons, R. J. \& ETHERden, I. (1983). Comparative hydrophobicity of oral bacteria and their adherence to salivary pellicles. Infection and Immunity 41, 11911196.

hogt, A. H., Dankert, J., de Vries, J. A. \& Feijen, J. (1983a). Adhesion of coagulase-negative staphylococci to biomaterials. Journal of General Microbiology 129, 2959-2968. 
Hogt, A. H., Dankert, J. \& Feijen, J. (1983b). Encapsulation, slime production and surface hydrophobicity of coagulase-negative staphylococci. FEMS Microbiology Letters 18, 211-215.

ICHIMAN, Y. \& YoshIDA, K. (1981). The relationship of capsular type of Staphylococcus epidermidis to virulence and induction of resistance in the mouse. Journal of Applied Microbiology 51, 229-241.

Kloos, W. E. \& Schleifer, K. H. (1975). Simplified scheme for routine identification of human Staphylococcus species. Journal of Clinical Microbiology 1, 8288.

Locci, R., Peters, G. \& Pulverer, G. (1981). Microbial colonization of prosthetic devices. III Adhesion of staphylococci to lumina of intravenous catheters perfused with bacterial suspensions. Zentralblatt für Bakteriologie, Mikrobiologie und Hygiene (Abteilung I) 173, 300-307.

OFEK, I. \& BEACHEY, E. H. (1980). General concepts and principles of bacterial adherence in animals and man. In Bacterial Adherence. Receptors and Recognition, Series B, vol. 6, pp. 1-31. Edited by E. H. Beachey. London \& New York: Chapman \& Hall.

OfEK, I., WITNACK, E. \& BEACHEY, E. H. (1983). Hydrophobic interactions of group A streptococci with hexadecane droplets. Journal of Bacteriology 154, 139-145.

Olsson, J. \& Westergren, G. (1982). Hydrophobic surface properties of oral streptococci. FEMS Microbiology Letters 15, 319-323.

van Oss, C. J. \& Gillman, C. F. (1972). Phagocytosis as a surface phenomenon II. Contact angles and phagocytosis of encapsulated bacteria before and after opsonization by specific antiserum and complement. Journal of the Reticuloendothelial Society 12 , 497-502.
Pedersen, K. (1981). Electrostatic interaction chromatography, a method for assaying the relative surface charges of bacteria. FEMS Microbiology Letters 12, 365-367.

ReYNolds, E. C. \& Wong, A. (1983). Effect of adsorbed protein on hydroxyapatite zeta potential and Streptococcus mutans adherence. Infection and Immunity 39, 1285-1290.

Rosenberg, E., Kaplan, N., Pines, O., Rosenberg, M. \& GuTNICK, D. (1983). Capsular polysaccharides interfere with adherence of Acinetobacter calcoaceticus to hydrocarbon. FEMS Microbiology Letters 17 , $157-160$.

Rosenberg, M. (1984). Bacterial adherence to hydrocarbons: a useful technique for studying cell surface hydrophobicity. FEMS Microbiology Letters 22, 289-295.

Rosenberg, M., Gutnick, D. \& Rosenberg, E. (1980). Adherence of bacteria to hydrocarbons: a simple method for measuring cell-surface hydrophobicity. FEBS Microbiology Letters 9, 29-33.

RUTTER, P. R. \& VINCENT, B. (1980). The adhesion of micro-organisms to surfaces: physico-chemical aspects. In Microbial Adhesion to Surfaces, pp. 79-92. Edited by R. C. W. Berkeley, J. M. Lynch, J. Melling, P. R. Rutter \& B. Vincent. Chichester: Ellis Horwood.

Wood, J. M. (1980). The interaction of microorganisms with ion exchange resins. In Microbial Adhesion to Surfaces, pp. 163-185. Edited by R. C. W. Berkeley, J. M. Lynch, J. Melling, P. R. Rutter \& B. Vincent. Chichester: Ellis Horwood.

Yoshida, K. \& MineGishi, Y. (1979). Isolation of an encapsulated strain of Staphylococcus epidermidis. Journal of Applied Bacteriology 47, 299-301. 